\title{
Effect of Packing Types on the Dimensional Accuracy of Denture Base Resin Cured by the Conventional Cycle in Relation to Post-pressing Times
}

\author{
Rafael Leonardo Xediek CONSANI ${ }^{1}$ \\ Saide Sarckis DOMITTI ${ }^{1}$ \\ Marcelo Ferraz MESQUITA ${ }^{1}$ \\ Simonides CONSANI ${ }^{2}$ \\ ${ }^{1}$ Department of Prosthodontics, and ${ }^{2}$ Department of Dental Materials, \\ School of Dentistry of Piracicaba, UNICAMP, Piracicaba, SP, Brazil
}

\begin{abstract}
This study investigated the dimensional stability of denture bases influenced by packing methods, in relation to post-pressing times, in the Clássico acrylic resin which was prepared according to manufacturer recommendations. Forty maxillary wax bases were made and randomly assigned into 2 groups of 20 specimens each according to the conventional and RS system packing methods. In each method, the specimens were subdivided into immediate, 6,12 and $24 \mathrm{~h}$ post-pressing times. The dough of the acrylic resin was packed in metallic flasks and processed in a water bath curing cycle at $74^{\circ} \mathrm{C}$ for $9 \mathrm{~h}$. After cooling at room temperature, the bases were removed from the flasks, finished and fixed on stone casts with instantaneous adhesive. The resin base-stone cast sets were transversally sectioned into 3 sections and the base-stone gap measured at 5 points in each section. The data were submitted to ANOVA and Tukey's test, which showed that the RS system had a smaller base distortion compared to conventional packing, with the exception of the 24-h post-pressing time. There was a statistically significant difference between the packing methods only in section $\mathrm{C}$ (posterior palatal zone). In the conventional packing method, the immediate and $6 \mathrm{~h}$ times demonstrated values with no statistically significant difference between them, as well as between the 12 and $24 \mathrm{~h}$ post-pressing times.
\end{abstract}

Key Words: dimensional change, denture base, packing methods, post-pressing time.

\section{INTRODUCTION}

A critical factor in the retention and stability of the complete denture is the dimensional change that occurs during polymerization shrinkage (1-4). This change may be partially compensated by water absorption (5), by the resilience of the gengival mucosa (6), and by the saliva film formed between the resin base and the soft support tissue $(7,8)$.

In addition, the base is also responsible for artificial teeth fixation and distribution of chewing forces over the tissue-bearing area, and other factors may influence the base dimensional stability, such as the resin-flasking method and the time-temperature correlation during the curing methods (9).
Some authors consider the most effective curing method to be the conventional cycle in a water bath at least $65^{\circ} \mathrm{C}$ for $9 \mathrm{~h}(10,11)$. Therefore, the dimensional change of the denture processed by different techniques may not be compensated after the resin base processing (12). The inaccuracy in the flange area may also cause instability and pressure points on the soft tissues, and the greatest effect of linear shrinkage is usually on the posterior palatal region of the maxillary denture, resulting in a gap between this area and the denture (13-15). A close adaptation to the soft tissue is required for the stability of a denture and the most important physical force in the retention is the saliva film thickness (16).

The combination of several factors such as polymerization shrinkage, thermal contraction by flask 
cooling, and strain caused by stress release during deflasking causes diminished adaptation of the denture to the tissue. Therefore, the discrepancy between the base and supporting tissues is an important factor in the control of the amount of force necessary to dislodge the dentures (17). The stress released later, gain or loss of water, and incomplete denture polymerization are factors responsible for the dimensional change occurring after removal of the denture from the stone cast and the most likely causes for denture instability (18). However, the magnitude of these changes is not large and, in almost all instances, it is within the range of -0.1 to $0.4 \%$ and, according to patient reaction, these changes do not significantly affect the serviceability of the denture (19).

The purpose of this study was to verify the dimensional change of the denture bases processed according to the conventional and RS system packing methods in relation to the immediate, 6,12 and $24 \mathrm{~h}$ acrylic resin post-pressing times.

\section{MATERIAL AND METHODS}

Forty maxillary stone casts were poured in Herodent Soli-Rock class III dental stone (Vigodent, Rio de Janeiro, RJ, Brazil) using a ratio of $30 \mathrm{~mL}$ water to $100 \mathrm{~g}$ powder. The stone casts were randomly assigned into 2 groups of 20 specimens each according to the conventional and RS tension packing methods. In each method, the specimens were subdivided into immediate, 6,12 and $24 \mathrm{~h}$ post-pressing times.

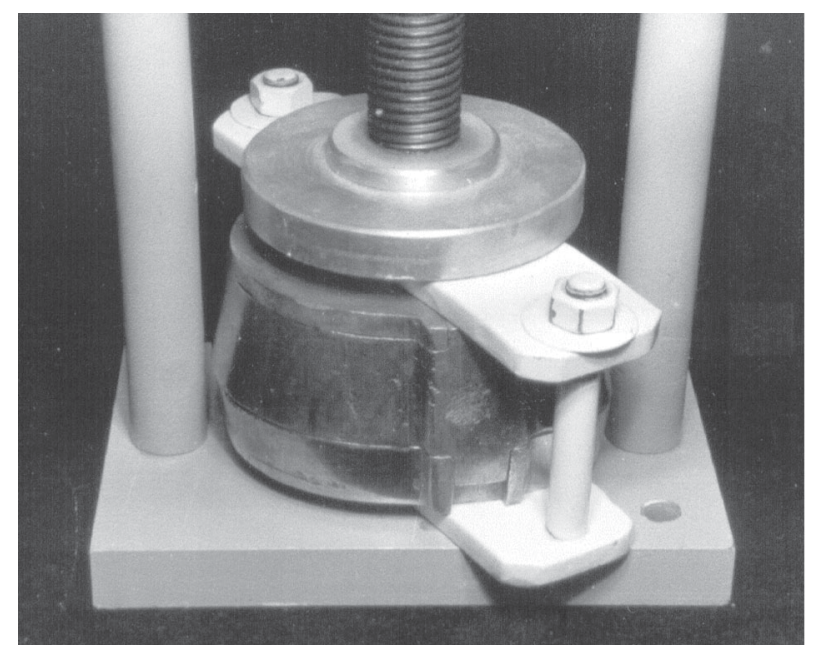

Figure 1. Flask pressed between the metallic plaques of the RS tension system.
A uniform denture baseplate wax pattern was made on each stone cast with a $1.5 \mathrm{~mm}$ thickness. The casts with wax patterns were invested in dental stone according to routine procedures. The samples were flasked in the lower part of traditional brass flasks with Star class II dental plaster (Chaves, Fortaleza, CE, Brazil). Petroleum jelly was used as a separating medium between the plaster in the lower part of the flask and the Herodent Soli-Rock class III dental stone used in the upper portion. After 1 hour, the flasks were placed in boiling water to soften the baseplate wax. The flask parts were separated, the wax removed, and the stone cleaned with boiling water and liquid detergent (ODD, Bombril-Cirio, São Paulo, SP, Brazil). Two coats of Isolak sodium alginate (Clássico Dental Products, São Paulo, SP, Brazil) were used as a mould separator.

Clássico standard PMMA (Clássico Dental Products, São Paulo, SP, Brazil) was used with a monomer:polymer ratio of 1:3 (by volume). The recommended mixing ratio of $37.5 \mathrm{~g}$ powder to $15 \mathrm{~mL}$ liquid was used according to manufacturer instructions for each flask pressing. The prepared dough was packed according to one of the post-pressing times for both conventional and RS system packing methods. A plastic sheet was used as a separating medium between the gypsum and the acrylic resin during the initial flasking closure. After the flask was opened, the plastic sheet was removed and the acrylic resin excess trimmed. In the conventional packing method, the final closure was performed using a Linea H 2000 hydraulic press (São Paulo, Brazil) with a load of $1.250 \mathrm{kgf}$ for $5 \mathrm{~min}$. The flasks were transferred to a flask carrier and immersed in water according to the post-pressing times and maintained at $74^{\circ} \mathrm{C}$ for $9 \mathrm{~h}$. In the RS system packing method, the final closure was made with a similar pressure condition and performed with the flask set between the two plaques of the RS system method. The system is an

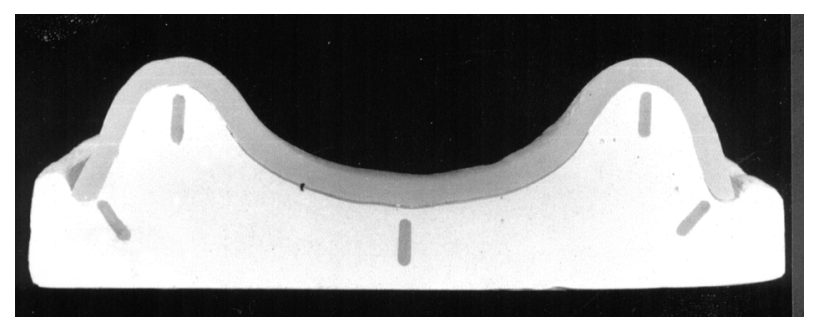

Figure 2. Points in the transverse sections used to determine the dimensional changes in the base-stone set. 
assembly composed of 2 iron plaques (150x40x8 mm). The lower plaque possesses a screw, $9 \mathrm{~mm}$ in diameter, soldered at each end. The upper part possesses 2 holes, with a cross section diameter of $10 \mathrm{~mm}$, in which the screws are trespassed before final flask closure. After final flask closure, the screw-nuts are turned in the screws (Figure 1) before press releasing to avoid resin mass distortion by opening the two flask parts. After the post-pressing times, all flasks were immersed in water and maintained at $74^{\circ} \mathrm{C}$ for $9 \mathrm{~h}$.

After the curing cycle, the flasks were removed and allowed to bench cool before the bases were deflasked, trimmed, and fixed onto their corresponding casts with Super Bonder instantaneous adhesive (Loctite, São Paulo, SP, Brazil) placed on the ridge crest of the stone cast. The resin base-stone cast sets were transversally sectioned into 3 sections, corresponding to the distal of canines (A), mesial of first molars (B), and posterior palatal zone $(\mathrm{C})$. The gap between the resin base and stone cast was measured at five points in the right and left ridge crests, at the midline, and at the right and left marginal limits (Figure 2) using a Leitz linear optical comparator microscope (Wetzlar, Germany) with a travelling stage capable of measuring $0.001 \mathrm{~mm}$. Each measurement was repeated three times and the average was used as the linear gap distance for that point. The measurements were made at 5 points for each one of the 3 sections, until the completion of 5 samples averaged together in each individual section.

Table 1. Dimensional change (means $\pm \mathrm{SD} ; \mathrm{mm}$ ) in the denture base in relation to post-pressing time and packing method.

\begin{tabular}{llc}
\hline Post-pressing time & \multicolumn{2}{c}{ Packing method } \\
\cline { 2 - 3 } & Conventional & RS system \\
\hline Immediate & $0.210 \pm 0.054^{\mathrm{a}}$ & $0.165 \pm 0.057^{*}$ \\
6 hours & $0.196 \pm 0.073^{\mathrm{a}}$ & $0.162 \pm 0.034^{*}$ \\
12 hours & $0.171 \pm 0.018^{\mathrm{b}}$ & $0.142 \pm 0.032^{*}$ \\
24 hours & $0.142 \pm 0.035^{\mathrm{b}}$ & $0.159 \pm 0.035$ \\
\hline
\end{tabular}

$* \mathrm{p}<0.05$ compared to conventional method at the same postpressing time.

${ }^{\mathrm{a}} \mathrm{p}>0.05$, immediate and $6 \mathrm{~h}$ post-pressing times in the conventional method.

${ }^{b} p>0.05,12$ and $24 \mathrm{~h}$ post-pressing times in the conventional method.

There were no statistically significant differences among postpressing times in the RS system.
The data were submitted to ANOVA and Tukey's test at a level of significance of $5 \%$.

\section{RESULTS}

The base discrepancies influenced by the acrylic resin packing methods independently of the other factors showed that the RS system method $(0.164 \pm 0.040)$ was significantly different $(\mathrm{p}<0.05)$ compared to the conventional method $(0.177 \pm 0.055)$.

The dimensional change values due to the packing methods influenced by post-pressing times (Table 1) showed statistically significant differences in the immediate, 6 and $12 \mathrm{~h}$ post-pressing times. In the 24 $\mathrm{h}$ post-pressing time, the discrepancy values for the RS system $(0.159 \pm 0.035)$ was similar compared with the conventional packing method $(0.142 \pm 0.035)$. In the conventional method, the values for the immediate and $6 \mathrm{~h}$ post-pressing times were statistically similar as were the 12 and $24 \mathrm{~h}$ times. There was no statistically significant difference among the post-pressing times in the RS system packing method.

Independently of the post-pressing times (Table 2 ), the results analyzed in the 3 sections showed statistically significant differences between the two packing methods only in section $\mathrm{C}$ (posterior palatal zone). In this section, the RS system promoted less discrepancy when compared to the conventional method.

\section{DISCUSSION}

The dimensional change occurring during the complete denture procedure has been recognized by several authors $(4,15,18)$ and still continues to be the major disadvantage of the process.

Table 2. Dimensional change (means $\pm \mathrm{SD} ; \mathrm{mm}$ ) in the denture base in relation to section and packing method.

\begin{tabular}{lccc}
\hline Packing method & \multicolumn{3}{c}{ Section } \\
\cline { 2 - 4 } & A & B & C \\
\hline Conventional & $0.144 \pm 0.020$ & $0.159 \pm 0.040$ & $0.227 \pm 0.058$ \\
RS system & $0.141 \pm 0.025$ & $0.144 \pm 0.026$ & $0.208 \pm 0.027^{*}$
\end{tabular}

Sections: $\mathrm{A}=$ distal of canines; $\mathrm{B}=$ mesial of first molars; $\mathrm{C}=$ posterior palatal zone.

$* \mathrm{p}<0.05$ compared to section $\mathrm{C}$ of conventional method. 
In this study, the smaller values for the RS system packing method compared with the conventional method, independently of the other factors, indicates that the dimensional change occurred in the denture base was influenced by the resin packing method.

When the post-pressing time was analyzed, the smaller base discrepancies occurred at immediate, 6 and $12 \mathrm{~h}$ post-pressing times. This fact signifies that the RS system packing method was not able to decrease the discrepancy occurred at $24 \mathrm{~h}$ in the conventional packing method, probably influenced by the longer delay prior to the resin curing start. An earlier study also demonstrated smaller discrepancy when the denture base was processed by the conventional curing cycle after 12 and $24 \mathrm{~h}$ post-pressing times (20).

The base stability depends only upon the nature of the stress produced during processing as well as its later release which is responsible for the greatest dimensional change occurring after the denture deflasking and is considered to be the most likely cause of denture dimensional stability (18). This study shows that the RS system packing method, which avoids flask opening, influenced the magnitude of the stress release when compared to conventional packing, which permits flask opening prior to placing the flask in the clamp.

Although the RS tension packing method decreased the dimensional change magnitude, base distortion is an inevitable shortcoming of the acrylic resin and one of the factors that may contribute to the level of denture stability, independently of the postpressing time at which the resin is cured afterwards.

Previous reports have demonstrated that the denture base presents the greatest discrepancy at the posterior palatal seal $(3,8,12,16)$. In this study, the mean dimensional changes incurred in both packing methods were statistically different only in section C, independently of the post-pressing times. The RS system packing method had a greater influence in section $\mathrm{C}$, where the gap magnitude was smaller than that obtained by the conventional packing method. This result showed that the RS system was able to decrease the stress release in this sealing area, improving the base adaptation on the stone cast.

The greatest mean discrepancies of the processed denture base were observed in section $\mathrm{C}$ with both resin-packing methods. An earlier study showed that discrepancies ranging from 0.23 to $0.58 \mathrm{~mm}$ may not be easily corrected after base processing (12). The discrepancies obtained in this study with the RS system were smaller than that shown in the literature, and may be able to produce a more accurate denture base, minimizing the inaccuracies promoted by the conventional resin packing procedure. This degree of dimensional change that occurred in the denture posterior palatal seal was also noted in previous studies investigating other denture procedure variables $(8,13,14)$.

The acrylic resin post-pressing times established in this study for the start of the curing cycle was not the most significant factor in determining the magnitude of the dimensional changes occurring in the RS system packing method. The discrepancy means did not demonstrate statistically significant differences among all post-pressing times. This fact may be due to the similar stress release promoted by the RS system packing method during the acrylic resin flask pressure.

Conversely, when the conventional packing method was considered, the statistical similarities were coupled between immediate and $6 \mathrm{~h}$, and between 12 and $24 \mathrm{~h}$ post-pressing times. In this packing method, the delay in the curing start may have influenced the dimensional change magnitude allowing the statistical similarity to be observed only between close postpressing times. Thus, the shorter times showed values with greater discrepancy when compared with the longer post-pressing times. Less denture base discrepancy was also demonstrated in an earlier study when the acrylic resin dough was processed in the conventional curing cycle after the 12 and $24 \mathrm{~h}$ post-pressing times (20).

Similar levels of relieved internal stress from the resin mass before the curing cycle in the immediate, 6 , 12 and 24 hours post-pressing times in the RS system packing method were responsible for these results with no statistically significant differences. This influence was not verified in the conventional packing method due to the prior stress relief before the curing cycle. After denture deflasking, the distortion caused by the relieved stress was more evident in the posterior palatal seal, a region more susceptible to strain when compared with the anterior and median zones.

This study showed that there was a statistically significant difference between the packing methods with the best results for the RS system packing method. The post-pressing times did not influence the dimensional change values of the denture base when the RS packing method was used. 


\section{RESUMO}

Este estudo investigou a alteração dimensional de bases de prótese total influenciada pelos métodos de prensagem em relação ao tempo de pós-prensagem da resina acrílica Clássico, proporcionada e manipulada de acordo com as recomendações do fabricante. Quarenta bases superiores em cera foram feitas e separadas aleatoriamente em 2 grupos de 20 corpos-de-prova de acordo com os métodos de prensagem convencional e pelo sistema RS de contensão. Em cada método os corpos-de-prova foram divididos de acordo com os tempos pós-prensagem imediato, 6, 12 e 24 horas. A massa de resina acrílica foi prensada em mufla metálica e polimerizada em banho de água aquecida a $74^{\circ} \mathrm{C}$ por 9 horas. Após esfriar em temperatura ambiente, as bases de resina foram removidas das muflas, acabadas e fixadas nos modelos de gesso com adesivo instantâneo. $\mathrm{O}$ conjunto base de resina-modelo de gesso foi seccionado transversalmente em 3 secções e o espaço entre base-modelo medido em 5 pontos em cada secção. Os resultados foram submetidos à ANOVA e ao teste de Tukey ( $5 \%$ ) e demonstraram que: o sistema RS promoveu menor distorção da base quando comparado com a prensagem convencional, com exceção do tempo pós-prensagem de 24 horas. Houve diferença estatística significativa entre os métodos de prensagem somente na secção C. No método convencional, os tempos imediato e de 6 horas mostraram valores sem diferença estatística significativa entre si, assim como entre os tempos pósprensagem 12 e 24 horas.

\section{REFERENCES}

1. Harman IM. Effects of time and temperature on polymerization of a methacrylate resin denture base. J Am Dent Assoc 1949;38: 188-203.

2. Peyton FA. Packing and processing denture base resins. J Am Dent Assoc 1950;40:520-528.

3. Anthony DH, Peyton FA. Evaluations of dimensional accuracy of denture bases with a modified comparator. J Prosthet Dent 1959; 9:683-692.

4. Becker CM, Smith DE, Nicholls JI. The comparison of denturebase processing techniques. II. Dimensional changes due to processing. J Prosthet Dent 1977;37:450-459.

5. Wong DMS, Cheng LYY, Chow TW, Clark, RKF. Effect of processing method on the dimensional accuracy and water sorp- tion of acrylic resin dentures. J Prosthet Dent 1999;81:300-304.

6. Jacobson TE, Krol AJ. A contemporary review of the factors involved in complete dentures. Part III: Support. J Prosthet Dent 1983;49:306-313.

7. Craig RG, Berry GC, Peyton FA. Physical factors related to denture retention. J Prosthet Dent 1960;10:459-467.

8. Polyzois GL. Improving the adaptation of denture base by anchorage to the casts: a comparative study. Quintessence Int 1990;21:185-190.

9. Yeung KC, Chow TW, Clark RKF. Temperature and dimensional changes in the two-stage processing technique for complete dentures. J Dent 1995;23:245-253.

10. Zissis A, Huggett R, Harrison A. Measurement methods used for the determination of dimensional accuracy and stability of denture base materials. J Dent 1991;19:199-206.

11. Anusavice KJ. Phillip's science of dental materials. 10th ed. Philadelphia: WB Saunders; 1996.

12. Chen JC, Lacefield WR, Castleberry DJ. Effect of denture thickness and curing cycle on the dimensional stability of acrylic resin dentures during processing. Dent Mater 1988;4:20-24.

13. Consani RLX, Domitti SS, Rizzatti-Barbosa CM, Consani S. Effect of commercial acrylic resins on the dimensional accuracy of the maxillary denture base. Braz Dent J 2002;13:57-60.

14. Firtell DN, Green AJ, Elahi JM. Posterior peripheral seal distortion related to processing temperature. J Prosthet Dent 1981;45:598-601.

15. Sanders JL, Levin B, Reitz PV. Comparison of adaptation of acrylic resin cured by microwave energy and conventional water bath. Quintessence Int 1991;22:181-186.

16. Turck MD, Lang BR, Wilcox DE, Meiers JC. Direct measurement of dimensional accuracy with three denture-processing techniques. Int J Prosthodont 1992;5:367-372.

17. Takamata T, Setcos JC, Phillips RW, Boone ME. Adaptation of acrylic resin denture as influenced by the activation mode of polymerization. J Am Dent Assoc 1989;119:271-276.

18. Grunewald AH, Paffenbarger GC, Dickson G. The effect of molding processes on some properties of denture resins. J Am Dent Assoc 1952;44:269-284.

19. Mowery WE, Burns CL, Dickson G, Sweeney WT. Dimensional stability of denture base resins. J Am Dent Assoc 1958;57:345353.

20. Consani RLX, Domitti SS, Correr Sobrinho L, Sinhoreti MAC. Efeito do tempo pós-prensagem da resina acrílica na alteração dimensional da base de prótese total. Pesqui Odontol Bras 2001;15:112-118.

Accepted July 16, 2002 